\title{
Firm Performance and Corporate Disclosure Level of Listed Companies in Nigeria
}

\author{
Kennedy Prince MODUGU, PhD \\ Assistant Professor \\ College of Financial and Administrative Sciences \\ AMA International University, Bahrain
}

Received: July 21, 2017 Accepted: Sep. 20, $2017 \quad$ Published: December 1, 2017

doi:10.5296/ajfa.v9i2.11778 URL: https://doi.org/10.5296/ajfa.v9i2.11778

\begin{abstract}
The study investigates the relationship between firm performance (proxied by profitability and liquidity) and corporate disclosure in Nigerian listed firms. The data used in the study were obtained from the annual reports of 60 companies listed on the Nigerian Stock Exchange from the various sectors of the country's economy. The study covers the post International Financial Reporting Standards (IFRSs) adoption period of three years (2012 2014). Corporate disclosure (dependent variable) was disaggregated into mandatory, voluntary and total disclosure. The data were analysed using both descriptive statistics and the Ordinary Least Squares (OLS) regression. Findings from the descriptive statistics reveal that, contrary to prior findings, there is a steady improvement in mandatory disclosure by Nigerian companies since the country's adoption of IFRSs. However, voluntary disclosure still remains relatively low. The regression results show no significant relationship between profitability and the three components of corporate disclosure. But liquidity shows a significant positive relationship with mandatory and total disclosure. The combined effect of profitability and liquidity shows no significant relationship with any of the components of corporate disclosure. The findings suggest that improved performance of companies does not necessarily induce them to disclosure more information as widely reported by previous researchers. These findings notwithstanding, the decision to disclose sufficiently and timely must be accorded priority attention by companies, considering the critical role of adequate and timely information disclosure in the global marketplace.
\end{abstract}

Keywords: Firm performance, corporate disclosure, profitability, liquidity, IFRS 


\section{Introduction}

Annual reports and accounts of corporate organisations are the vehicles for communicating useful economic information about the operations of companies to diverse users. These users include shareholders, management, employees, suppliers, creditors, financial analysts, labour unions, stockbrokers, regulators, government agencies and the public. These users rely on published financial and non-financial reports of corporate organisations to make informed decisions. It therefore connotes that the quality of decisions made by users depends largely on the quality and quantity of available information.

The last two decades witnessed large-scale corporate scandals, majority of which are attributable to either non-disclosure or under-disclosure of actual operations of corporate establishments. In the US for example, the Enron debacle raised a retinue of questions on the transparency of corporate disclosure. In the wake of this debacle, a plethora of reforms were promulgated by the US government to strengthen corporate governance practices in general and corporate disclosure in particular. Whereas developed economies have made efforts to improve the quality of corporate disclosure through the establishment of virile institutions saddled with the responsibility of corporate reporting transparency, most developing countries still lag behind in this drive. If the former with stronger institutions and technological advancement still record incidences of poor disclosures, it suggests that the latter with weak institutions and emerging business environment may be worse. For example, Nigeria has been reputed for low-quality financial reporting occasioned by poor accounting system and weak corporate governance institutions (Okike, Adegbite, Nakpodia, \& Adegbite, 2015). Over time, financial reports in Nigeria have been found to be deficient (Wallace, 1988; Adeyemi, 2006; Nweke, 2009) in that they lack vital information that will enable stakeholders to make informed decisions. It is therefore imperative to further investigate the compliance level of Nigerian companies with the corporate disclosure requirements in Nigeria following the adoption of the International Financial Reporting Standards (IFRS). This is with a view to understanding the Nigerian financial reporting environment and identify the information needs of the diverse users in orders to adequately provide them with the appropriate mix of accounting information.

Despite the collective efforts of the International Accounting Standards Board (IASB) and the global financial community to improve the quality of corporate reporting which led to the introduction of IFRS and its subsequent adoption by a significant number of companies, the abuse of corporate reporting remains unabated across the globe (Okunbor, 2016). Recent evidence of the prevalence of serious accounting and reporting fraud include BES 2014 scandal in which the giant Portuguese bank made a loss of $€ 3.6 \mathrm{bn}$ leading to the revocation of its operating license on account of serious misrepresentation and deliberate concealment of the bank's information by the directors. Also the CEO of Toshiba, a Japanese company, Hisao Tanaka resigned alongside other seven senior officers in 2015, after an independent inquiry revealed that the CEO had been aware that the company had inflated its profits by $\$ 1.2$ billion for several years. The findings are expected to lead to the restatement of earnings and the imposition of heavy fines on Japan's worst accounting scandal since 2011, when Olympus Corporation admitted to using takeovers to hide $\$ 1.7$ billion in losses (Ando, 2015). 
In 2016 Weatherford International plc, a US oil services company was fined \$140m by the US Securities and Exchange Commission (SEC) for fraudulently raising its earnings by over $\$ 900 \mathrm{~m}$ through of income tax accounting fraud. The company perpetrated this act through its former vice president of tax James Hudgins and former tax manager Darryl Kitay. The duo fraudulently reduced the company's year-end income tax provisions by $\$ 100 \mathrm{~m}$ to $\$ 154$ for four years.

SEC in its administrative order against Weatherford and its officers asserts thus:

"Between 2007 and 2012, Weatherford, a large multinational provider of oil and natural gas equipment and services, issued false financial statements that inflated its earnings by over \$900million in violation of U.S. Generally Accepted Accounting Principles (GAAP).Weatherford issued materially false and misleading statements about its net income, earnings per share ("EPS"), effective tax rate ("ETR"), and other key financial information. Weatherford did not have sufficient internal accounting controls to identify and properly account for its accounting of income taxes throughout the relevant period" (SEC, 2016, p.2)

SEC said that the adjustments allowed reported effective tax rate (ETR) and earnings results to better align with Weatherford's analysts' expectations and Weatherford's previously-announced projected results. In addition to the $\$ 140$ million civil penalty fine; Hudgins and Kitay agreed to pay $\$ 334,067$ and $\$ 30,000$ fine respectively.

Also accused by SEC was Weatherford's external auditors, Ernst \& Young (EY) between 2001 and 2013 for failing to comply with Public Companies Accounts Oversight Board (PCAOB). SEC accused EY of a significant audit failure, for ignoring red flags as Weatherford accumulated a phantom \$461 million income tax receivable between 2007 and 2010 by overstating net income and understating its effective tax rate, a financial irregularity that EY failed to report. For this professional negligence, EY was fined $\$ 11.8 \mathrm{~m}$.

Against this background, this study investigates the relationship between firm performance variables and corporate disclosure level of Nigerian companies with a view to prescribe avenues for raising the bar of transparency in corporate reporting in Nigeria.

\section{Literature Review}

\subsection{Corporate Disclosure Defined}

The concept of corporate disclosure seems amorphous. Attempts at conceptualizing and measuring it have not yielded a universal approach for researchers (Modugu \& Eboigbe, 2017). For instance, Abu-Nassar (1993) contends that a singular definition of disclosure is practically unattainable. This, according to him, is tasking being that the objects being measured are people's needs, perception, and attitudes which are qualitative rather than quantitative. Cooke and Wallace (1989) assert that disclosure is an abstract concept that cannot be measured directly. It does not possess inherent characteristics by which one can determine its intensity or quality like the capacity of a car.

One of the earliest definitions of disclosure is given by Kohler (1957) (as cited in Abdulrahman, 1998). He describes disclosure as a clear showing of the fact or conditions on 
the balance sheet or other financial statements, in the footnote thereto, or in the audit report. Also, Choi (1973) defines disclosure as "the publication of any economic datum relating to a business enterprise, quantitative or otherwise, which facilitates the making of economic decisions" (p. 123). According to him, economic data consist of information which prunes the uncertainty that is characteristic of the outcome of future economic events, and that improved disclosure is a function of increased quantity and quality of economic data available to investors through financial statements. Gibbins, Richardson and Waterhouse (1990) define disclosure as "any deliberate release of financial information, whether numerical or qualitative, required or voluntary, via formal or informal channels" (p.122).

Parker (1992) defines disclosure as the reporting of financial and non-financial information to users of accounting reports, especially to investors, which can be made according to legislation or accounting standards or can be voluntary. Cooke (1992) "states that disclosure comprises mandatory and voluntary items of information provided in the financial statements, notes to the accounts, management's analysis of operations for the current and forthcoming year and any supplementary information" (p.231). Abdulrahman (1998), in reviewing the preceding definitions of disclosure posits that corporate disclosure is a wide-ranging term which goes beyond the annual reports. He, therefore, narrowed it down to suit his study. According to him, disclosure is the publication of any type of information through the corporate annual reports, which are necessary, relevant and material to the various user groups in making their judgements and decisions about a company. Lee (2012) (as cited in Hajian \& Rostami, 2014) believes that disclosure refers to an accurate and timely release of information about the business strategy, financial performance and corporate governance to the general public by a company.

According to Al-Zarouni (2008), "the definition of corporate disclosure varies and the concept itself covers a wide area. It goes beyond the corporate annual reports to cover information outside the financial statements, such as, discussion of competition, economic statistics and analysis of company"(p.45). Owusu-Ansah (1998a) and Wallace and Naser (1995) see disclosure as a communication of economic information, whether financial or non-financial, quantitative or otherwise concerning a company's financial position and performance. Disclosure results in a combination of mandatory and voluntary items that constantly interact with each other. Mandatory disclosure is a company's obligation to disclose a minimum amount of information in corporate reports (Owusu-Ansah, 1998a; Wallace \&Naser, 1995), whereas voluntary disclosure is a provision of additional information when mandatory disclosure is unable to provide a true state of a company's value and managers' performance. Voluntary disclosure is the release of additional information about a firm in excess of the statutorily required disclosure.

More recently, Solomon (2013) describes disclosure as a whole array of different forms of information produced by companies such as, the annual report and all forms of voluntary corporate communications. Okike et al (2015) observe that the annual report and accounts of a company act as the channel of communication from the directors to shareholders and are important for corporate governance because these reports provide the means by which the directors are made accountable to the shareholders. 
The existing definitions of disclosure are a testament to the broadness of the concept, as prior researchers have advanced definitions suitable for the scope of their respective studies. For over four decades of research into corporate disclosure, the concept was bereft of any known theory until Healy and Palepu (2001) as well as Omran and El-Galfy (2014) proposed a list of theories for disclosure. This lack of general theory, according to Abdulrahman (1998), was due to the abstract nature of disclosure which may mean several things to several people. This is why different researchers view the concept from different perspectives. The common perspectives include disclosure adequacy (Buzby, 1974; Al-Zarouni, 2008) and disclosure quality (Singhvi \& Desai, 1971; Moore \& Buzby, 1972).

In this study, disclosure is viewed as the fair presentation of an entity's financial or non-financial information whether mandatory or voluntary which is included in annual reports and is useful to stakeholders' decision making. Fundamentally, for the information to be useful, it must be relevant and faithfully represents that which it purports to represent. In addition, the information is enhanced if it is comparable, verifiable, timely and understandable.

\subsection{Relationship between Firm Performance and Corporate Disclosure}

According to Lang and Lundholm (1993), performance-related variables represent information to which management may have preferential access and which varies from time to time. These variables are profitability and liquidity. Firms may release information to signal good performance (Benston, 1980). Also, management may want to assure shareholders of the firm's profitability to justify management's compensation (Singhvi \& Desai, 1971). Lang and Lundholm (1993) argue that if performance serves as a proxy for information asymmetry between investors and managers, then disclosure may be related to the variability of a firm's performance. This means that disclosures increase when perceived management and investor information asymmetry is high.

\subsubsection{Profitability}

Theoretically, management tends to disclose more information when the firm is performing well than when it is performing poorly (Wallace et al. 1994). Also, in the presence of disclosure costs, firms disclose more information as their performance exceeds a certain threshold. Based on the signalling theory, researchers argue that a firm with a higher profitability is inclined to disclose more information in its annual report to signal its superior performance to the market (Cooke, 1989; Wallace, et al. 1994; Wallace \&Naser 1995; and Archambault \& Archambault, 2003). On the other hand, firms may voluntarily disclose information in order to justify their unexpected poor performance and to reduce the likelihood of a substantial negative stock price response in the event that a particular piece of information becomes a mandatory disclosure item (Skinner, 1995).

Empirical evidence on the direction of relationship between firm performance and disclosure is mixed and inconclusive. While some studies (Wallace et al. 1994; Naser, 1998; Naser et al. 2002) report that firms tend to disclose more information when they are experiencing favourable earnings results, others (Wallace \&Naser 1995) reported a negative and significant 
association between the two variables (Wallace et al. 1994; Naser et al. 2002, Umoren, 2009). Interestingly, some studies provide evidence that firms are more likely to disclose more information when they have bad news than for good news (Belkaoui \& Kahl, 1978; and Healy \& Palepu, 2001). Most prior studies use return on equity and return on sales/profit margin as a measure of profitability (Wallace et al., 1994; Wallace and Naser, 1995; Camfferman \& Cooke, 2002; Alsaeed, 2006).

\subsubsection{Liquidity}

Companies with high liquidity levels are more likely to disclose more information to show their superior performance to investors, regulatory authorities, and lenders, that they can fulfill their short term obligations and continue in operational existence (Shehata, Dahawy \& Ismail, 2014). However, companies with low liquidity levels may also disclose more information to avoid shareholders' claims, and to prove that management is aware of the company's problems (Wallace et al., 1994; Wallace \& Naser, 1995; Alsaeed, 2006). The majority of prior studies mentioned above use current ratio as a proxy for liquidity.A firm's liquidity has also been reported to be associated with its corporate disclosure level. Regulatory bodies, as well as investors and lenders, are more concerned about the going-concern status of firms (Wallace \&Naser, 1995; Naser et al. 2002). In view of this, firms that are able to meet their short-term financial obligations without recourse to the liquidation of their active non-current assets may desire to make this known through disclosure in their annual reports (Owusu-Ansah, 1998b; Naser \& Al-Khatib, 2000).

A firm's liquidity position can be measured by the ratio of the firm's current assets to current liabilities. Some argue that quick (acid-test) ratio; current assets less inventory to current liabilities, is a more stringent measure of corporate liquidity. However, empirical investigations have shown inconclusive results. For example, while Belkaoui and Kahl (1978) show that financially strong firms are more likely to disclose more information than their financially weak counterparts, Wallace et al. (1994), Wallace and Naser (1995), Naser and Al-Khatib (2002), and Naser, et al. (2002) find that liquidity is significantly and negatively associated with disclosure level. Other studies, however, find no such association (e.g., Owusu-Ansah 1998b; Alsaeed, 2005).

\section{Theoretical Framework}

This study is underpinned by the Positive Accounting Theory (PAT). Prior to the mid-1960s, accounting research was mainly normative, seeking to prescribe 'what should be' or 'what ought to be' in relation to accounting measurement and financial reporting. Normative accounting research failed to provide an empirical explanation to accounting practice (Omran $\&$ El-Galfy, 2014). This led to the development of positive accounting research to combat this limitation. PAT came into existence in the 1960s from the work of Fama on the Efficient Market Hypothesis. It was later popularized by Gordan (1964) who posits that senior management was likely to manipulate the information in the financial statements in their own favour by selecting accounting procedures that maximize their own utility (Umoren, 2009). According to Watts and Zimmerman (1990), early studies that applied PAT are Ball and Brown (1968) and Beaver (1968). PAT is an accounting theory which seeks to explain and 
predict how choices of accounting standards, methods, and information disclosure formats are made (Watts \& Zimmerman, 1990). It is based on the assumptions that preparers act opportunistically in making accounting choices, contracting how costing between an entity and its stakeholders influence the choice of accounting practices and that there is an explicit set of accounting choices to select from (Kiyanga, 2014).

Watts and Zimmerman (1986) highlight key hypotheses of PAT to include: the bonus plan hypothesis, debt/equity hypothesis and size hypothesis. The bonus plan hypothesis states that managers of entities with bonus plans are more likely to choose accounting procedures that shift reported earnings from future periods to the current period, other things being equal. The debt/equity hypothesis posits that the larger the debt/equity ratio, the more likely the entity's manager is to select accounting procedures that shift earnings from future periods to the current period, other things being equal. The size hypothesis states the larger the entity the more likely managers are to choose accounting procedures that defer reported earnings from the current to future periods, other things being equal. Kiyanga (2014) observes that so far, evidence from tests of the theory's hypotheses is consistent with the hypotheses, implying that the theory does explain and predict the choice of accounting practices.

However, Sternberg (1997) argues that the theory has several shortcomings. In the first place, it does not clarify whether the incentives for making accounting choices are economic, or efficient or social in nature. Secondly, the theory does not explain all accounting practices, as much remain unexplained. Thirdly, the implication of the theory that accounting choices are influenced by transactional costs only is not correct as there are other factors that influence the accounting choices made. For example, the nature of the entity, professional requirements, and industry practice may influence the choice of accounting practices (Gouws \& Cronje, 2008; Belkaoui, 2004). Lastly, the theory just focuses on the supply side of disclosure. The decision-making usefulness of the information disclosed does not feature as a factor influencing the choice. However, these shortcomings do not render the theory completely invalid.

PAT has a direct bearing on the research topic. In this study, corporate disclosure presents an excellent opportunity to apply PAT. This is premised on the fact that since managers (agents) have better access to companies' information, they can make credible and reliable communication to the market to optimise the value of the firm. Through financial reporting, managers communicate to the users of financial reports, information that is useful in making choices among alternative uses of scarce resources. On the contrary, the managers may fail to make proper disclosure of useful information to the users due to their opportunistic tendencies. Such practices will not be in the best interests of shareholders (principal). Consequently, this may result in higher cost of capital and lower value of shareholders' investments. 


\section{Methodology}

\subsection{Research Design, Sample and Data}

This study adopted the longitudinal research design. This is because it is useful in the studying of the current state of a unit or a group of items over a period of time. The content analysis approach which involves the construction of disclosure checklist from a list of annual report items was used. A disclosure index was developed from the checklist and used for the study. Historically, Cerf (1961) is the first researcher who conducted an empirical study using a disclosure index. He developed an index consisting of 31 items, each of which was scored on a scale of 1 to 4 on the basis of interviews with financial analysts. Cerf's approach, with extensions and modifications, has been used widely in many other studies (for example, Wallace, 1988; Lang \& Lundholm, 1993; Alsaeed, 2006; Umoren, 2009; Al-Zarouni, 2008; $\mathrm{Qu}, 2011$; Ibrahim, 2014) to examine the adequacy of corporate financial disclosure in different countries. Considering a given list of items, the value of the index for a particular company is obtained by dividing the number of information items disclosed by that company by the total number of information disclosure items that might be disclosed.

The total population consists of the 189 listed companies on the Nigerian Stock Exchange at $31^{\text {st }}$ December 2014 (Factbook, 2014). In estimating the sample size, the Yamane (1967) formula was used. The formula is chosen because of its simplicity and is considered as the most popular sampling design technique (Israel, 2013). In addition, the population is finite, making it amenable to the formula. This formula is given as:

$$
n=\frac{N}{1+N(e)^{2}}
$$

Where: $\quad \mathrm{n}=$ sample size

$\mathrm{N}=$ population

$\mathrm{e}=$ error limit $(0.05$ on the basis of $95 \%$ confidence level)

Therefore, $\quad \mathrm{n}=189 /\left[1+189\left(0.05^{2}\right)\right.$

$$
\begin{aligned}
& \mathrm{n}=189 / 1+189(0.0025) \\
& \mathrm{n}=189 / 1.4725 \\
& \mathrm{n}=128
\end{aligned}
$$

Based on the above sample of 128 firms, the simple random sampling technique was then adopted in selecting 60 firms from a stratified sample of thirty industries trading on the NSE between $1^{\text {st }}$ January 2012 and $31^{\text {st }}$ December 2014. This was to ensure that the relevant sectors have equal chances of being represented. The choice of 2012 to 2014 was informed by the fact that going by the roadmap for the adoption of IFRS by Nigerian 
companies which began on January 1, 2012 and ended on January 1, 2014, all public listed entities are expected to have fully complied by the year ended 2014 .

3.6 Model Specification and Variable Measurement

$$
\text { TDISC }_{\text {it }}=\partial_{0}+\partial_{1} \text { PROFIT }_{\text {it }}+\partial_{2} \text { LIQ }_{\text {it }}+\mu_{\text {it }}
$$

Where:

TDISC $=$ Total corporate disclosure

PROFIT $=$ Profitability

LIQ $=$ Liquidity

$\mu=$ the stochastic error term,

$i=$ number of sampled firms $(1,2, \ldots n)$,

$\mathrm{t}=$ time period of the sample companies.

The a priori expectations are:

$\eta_{1}>0$; implying that the higher the PROFIT, the higher the disclosure level,

$\eta_{2}>0$; implying that the higher the LIQ, the higher the disclosure level,

The model was adapted from previous empirical studies (Cerf, 1961; Wallace, 1987; Umoren, 2008; Al-Zarouni, 2008; Ibrahim, 2014) on corporate disclosure with some modifications.

Table 3.1. Operationalisation of Variables

\begin{tabular}{|l|l|l|l|c|}
\hline S/N & Variables & Codes & Measurement & A priori sign \\
\hline 1 & $\begin{array}{l}\text { Total disclosure } \\
\text { index }\end{array}$ & TDISC & $\begin{array}{l}\text { Summation of both } \\
\text { mandatory and } \\
\text { voluntary disclosure } \\
\text { indexes }\end{array}$ & \\
\hline 2 & Profitability & PROFIT & $\begin{array}{l}\text { Profit before interest } \\
\text { and taxes divided total } \\
\text { sales }\end{array}$ & + \\
\hline 3 & Liquidity & LIQ & $\begin{array}{l}\text { Current asset divided } \\
\text { by current liabilities }\end{array}$ & + \\
\hline
\end{tabular}

Source: Researcher's Compilation, 2016

\section{Empirical Results}

The study utilizes both descriptive statistics and the Pooled Ordinary Least Squares (OLS) estimation. The use OLS is a simple way to examine the sensitivity of the results to alternative specifications (Beaver, 1998) and allows for greater flexibility in modelling differences in sample specific behaviour (Greene, 2007). The results are presented and analyzed below: 
5.1 Descriptive Statistics

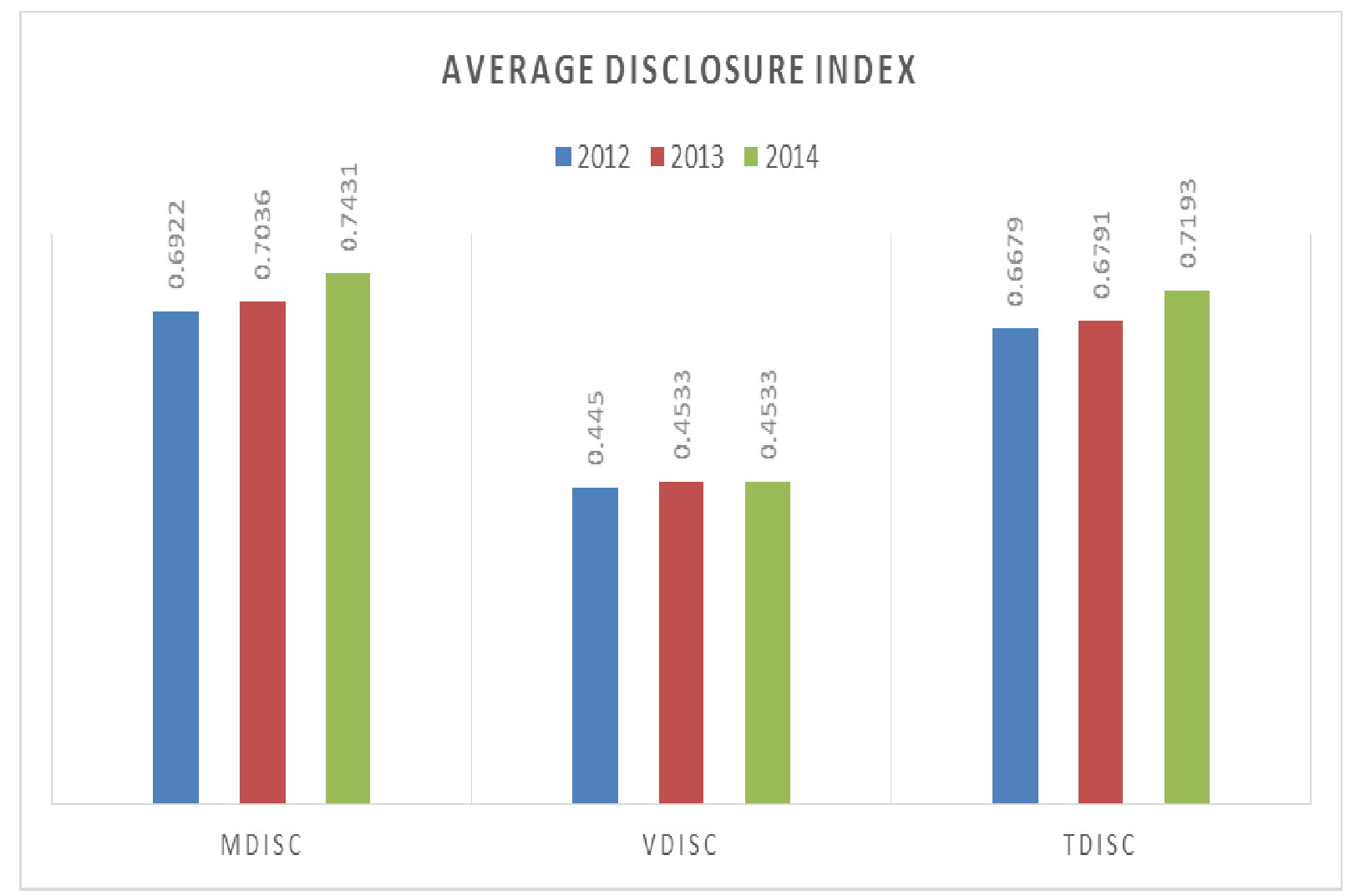

Source: Researcher's Compilation (2016)

Figure 5.1. Average Disclosure Index

Figure 5.1 above shows the average disclosure index for the distribution in the IFRS period covered in the study. As observed, for 2012, the average mandatory disclosure index was 0.692 and then increased to 0.7036 in 2013 and to 0.7431 in 2014. The above average index score suggest that most companies in the distribution did not fair to poorly in implementation of IFRS for 2012 reporting year. For voluntary disclosures (VDISC), the average indexes for 2012 was 0.445 , while 2013 and 2014 had the same index of 0.4533 . The results suggest that the pattern of voluntary disclosure in annual reports is still quite low arguably so because it is voluntary. There may also be a tendency for this category of disclosures to be largely repetitive over time. For total disclosures (TDISC), the average index for 2012, 2013 and 2014 are $0.6679,0.6791$, and 0.7193 respectively. The result shows some level of improvement in total disclosures emanating basically from improvements in mandatory disclosures. This may suggest that most companies have improved their disclosures subsequently after initial 2012 reporting year. 


\section{I Macrothink}

Asian Journal of Finance \& Accounting

ISSN 1946-052X

2017, Vol. 9, No. 2

Table 5.1. Regression Results

\begin{tabular}{|c|c|c|c|c|c|c|}
\hline Variables & MDISC & VDISC & TDISC & MDISC & VDISC & TDISC \\
\hline $\mathrm{C}$ & $\begin{array}{c}64.0631 \\
\{1.5343\} \\
(0.000)\end{array}$ & $\begin{array}{c}4.3816 \\
\{0.3981\} \\
(0.000)\end{array}$ & $\begin{array}{c}68.4817 \\
\{1.6259\} \\
(0.000)\end{array}$ & $\begin{array}{c}64.4207 \\
\{1.4281\} \\
(0.000)\end{array}$ & $\begin{array}{c}4.4449 \\
\{0.3974\} \\
(0.000)\end{array}$ & $\begin{array}{c}68.9055 \\
\{1.5147\} \\
(0.000)\end{array}$ \\
\hline PROFIT & $\begin{array}{c}-0.0732 \\
\{0.0505\} \\
(0.1492)\end{array}$ & $\begin{array}{c}0.0089 \\
\{0.0137\} \\
(0.5185)\end{array}$ & $\begin{array}{r}-0.0626 \\
\{0.0530\} \\
(0.2391)\end{array}$ & & & \\
\hline LIQ & $\begin{array}{c}0.6022^{*} \\
\{0.1561\} \\
(0.000)\end{array}$ & $\begin{array}{c}-0.0039 \\
\{0.0089\} \\
(0.6631)\end{array}$ & $\begin{array}{c}0.5898 * \\
\{0.1548\} \\
(0.000)\end{array}$ & & & \\
\hline FP-Index & & & & $\begin{array}{c}0.6665 \\
\{0.5487\} \\
(0.2261)\end{array}$ & $\begin{array}{r}-0.0064 \\
\{0.0247\} \\
(0.7964)\end{array}$ & $\begin{array}{c}0.6828 \\
\{0.5444\} \\
(0.2114)\end{array}$ \\
\hline $\operatorname{AR}(1)$ & $\begin{array}{l}0.6880 \\
\{0.111\} \\
(0.000)\end{array}$ & $\begin{array}{c}0.8543 \\
\{0.0472\} \\
(0.000)\end{array}$ & $\begin{array}{l}0.7005 \\
\{0.1077\} \\
(0.000)\end{array}$ & $\begin{array}{r}0.6767 \\
\{0.0966\} \\
(0.000)\end{array}$ & $\begin{array}{c}0.8543 \\
\{0.0589\} \\
(0.000)\end{array}$ & $\begin{array}{c}0.6862 \\
\{0.0949\} \\
(0.000)\end{array}$ \\
\hline $\mathrm{R}^{2}$ & 0.475 & 0.7310 & 0.4875 & 0.4585 & 0.7272 & 0.4733 \\
\hline $\mathrm{ADJ}^{2}$ & 0.466 & 0.7264 & 0.4787 & 0.4523 & 0.7241 & 0.4673 \\
\hline F-Stat & 52.8071 & 158.555 & 55.4833 & 74.0893 & 233.29 & 78.640 \\
\hline $\mathrm{P}(\mathrm{f}$-stat $)$ & 0.000 & 0.000 & 0.00 & 0.000 & 0.000 & 0.000 \\
\hline D.W & 2.2 & 1.9 & 2.2 & 2.2 & 1.9 & 2.2 \\
\hline S.E Regression & 6.087 & 0.7945 & 6.2738 & 6.1652 & 0.7241 & 6.336 \\
\hline Means of dependent var. & 64.413 & 4.502 & 68.916 & 64.4606 & 4.511 & 68.9719 \\
\hline
\end{tabular}

Source: Researcher's Computation (2016) * sig at 5\% \{ \} standard errors, ( ) p-values

Where: PROFIT= Profitability

LIQ= Liquidity

FP-index $=$ Firm performance Index derived using factor scores

Table 5.1 above shows the regression results of the effect of firm performance on corporate disclosure. As can be observed, three firm performance variables (PROFIT, LIQ and FP-factor score) were regressed on mandatory disclosure, voluntary disclosure and total disclosure. We first regressed the firm performance variables and then a firm performance index derived using factor scores. For mandatory disclosure (MDISC), the model properties reveal that the coefficient of determination $\left(R^{2}\right)$ and $A d j R^{2}$ are 0.475 and 0.466 respectively. These values 
suggest that the model explains only about $47.5 \%$ of systematic variations in mandatory disclosures with an adjusted value of $44.7 \%$ after controlling for degrees of freedom. The F-stat (52.807) and p-value (0.00) indicate the acceptance of the hypothesis of a significant linear relationship between the variables (dependent and independent) at 5\% level of significancewhile the D.W statistic of 2.2 indicates that a serial correlation presence in the residuals is unlikely. The effect of PROFIT is negative (-0.0732) though not significant at 5\% level $(p=0.1492)$. The effect of LIQ is positive (0.6022) and significant at $5 \%$ level $(p=0.000)$.

For voluntary disclosure (VDISC), the model properties reveal that the coefficient of determination $\left(\mathrm{R}^{2}\right)$ and $A d j R^{2}$ are 0.7310 and 0.726 respectively. These values suggest that the model explains only about $73.1 \%$ of systematic variations in mandatory disclosures with an adjusted value of $72.6 \%$ after controlling for degrees of freedom. The F-values confirm that the hypothesis of a significant linear relationship between the variables (dependent and independent) cannot be rejected at 5\% level while the D.W statistic of 1.9 indicates that a serial correlation presence in the residuals of the model is unlikely. The effect of PROFIT is positive (0.0089) though not significant at $5 \%$ level $(p=0.5185)$. The effect of LIQ is negative $(-0.0039)$ though not also significant at $5 \%$ level $(\mathrm{p}=0.6631)$.

For total disclosure (TDISC), the model properties reveal that the coefficient of determination $\left(\mathrm{R}^{2}\right)$ and $\mathrm{Adj} \mathrm{R}^{2}$ are 0.4875 and 0.4785 respectively. These values suggest that the model explains only about $48.7 \%$ of systematic variations in mandatory disclosures with an adjusted value of $47.8 \%$ after controlling for degrees of freedom. The F-values confirm that the hypothesis of a significant linear relationship between the variables (dependent and independent) cannot be rejected at 5\% level while the D.W statistic of 2.2 indicates that a serial correlation presence in the residuals of the model is unlikely. The effect of PROFIT is negative $(-0.0626)$ though not significant at $5 \%$ level $(\mathrm{p}=0.2391)$. The effect of LIQ is positive $(0.5898)$ and significant at $5 \%$ level $(\mathrm{p}=0.000)$.

Using the firm performance index, the model properties for MDISC; $\mathrm{R}^{2}=0.459, \operatorname{Adj}^{2}=0.452$, F-stat $=74.089$ and D.W $=2.2$. The effect of FP-Index is positive $(0.6665)$ though not significant at $5 \%$ level $(p=0.2261)$. For VDISC, the model properties are; $R^{2}=0.727, \operatorname{Adj}^{2}=$ $0.724, \mathrm{~F}$-stat $=233.29$ and D.W $=1$.9. The effect of FP-Index is negative $(-0.0064)$ though not significant at $5 \%$ level $(\mathrm{p}=0.7964)$. For TDISC, the model properties are; $\mathrm{R}^{2=} 0.4733$, Adj $\mathrm{R}^{2}$ $=0.4673, \mathrm{~F}$-stat $=78.640$ and D.W=2.2.The effect of FP-Index score is positive $(0.6828)$ though not also significant at $5 \%$ level $(\mathrm{p}=0.2114)$.

\section{Conclusion and Recommendations}

Prior studies have examined the relationship between firm performance and corporate disclosure. Results of these studies have been mixed regarding the direction and significance of the association between firm performance and corporate disclosure levels. In this study, we moved a step further to examine not only the individual relationships, but the combined effect of profitability and liquidity (represented by the factor score of both variables) on the extent of corporate disclosure in annual reports of listed companies in Nigeria. Furthermore, we disaggregated corporate disclosure into three components. They include mandatory disclosure, 
voluntary disclosure and total disclosure. This was to allow for the determination of the association between firm performance variables and individual corporate disclosure variant.

The results showed that the relationship between profitability and the three disclosure components of mandatory, voluntary and total disclosure is not significant. However, a significant positive relationship was observed between liquidity and the duo of mandatory and total disclosure; but not significant with voluntary disclosure. The combined effect of profitability and liquidity showed no significant relationship with the three components of disclosure total disclosure. The findings suggest that improved performance of companies does not necessarily induce them to disclosure more information as widely reported by previous researchers. These findings notwithstanding, the decision to disclose sufficiently and timely must be accorded priority attention by companies considering the critical role of such information in the global marketplace.

Based on the findings, we recommend that the Financial Reporting Council of Nigeria and other regulatory agencies should intensify efforts towards enforcement of companies' compliance with the requirement of IFRSs and other relevant statutory provisions. In addition, future empirical studies in this area should expand the number of years to include more recent years. This could be used to assess the trends of disclosure in order to confirm if there had been any improvement over time. Future researchers should attempt to increase the firm performance variables beyond those examined in this study.

\section{References}

Abdulrahman, A. (1998). Disclosure of corporate financial information in Malaysia.(Unpublished Doctoral Dissertation). University of Glasgow, Scotland, UK

Abu-Nassar, M. (1993).The development of financial reporting in Jordan: a survey of prepares' and users' attitudes and reporting practices (Unpublished Doctoral Dissertation). University of Kent at Canterbury, UK.

Adeyemi, S. B. (2006). Impact of accounting standards on financial reporting in Nigeria. Unpublished Doctoral Dissertation). University of Lagos, Nigeria

Alsaeed, K. (2005). The association between firm-specific characteristics and disclosure: The case of Saudi Arabia. The Journal of American Academy of Business, Cambridge, 7(1), 310-321.

Alsaeed, K. (2006). The Association between firm-specific characteristics and disclosure: The case of Saudi Arabia. Managerial Auditing Journal, 21(5), 476-496. https://doi.org/10.1108/02686900610667256

Al-Zarouni, A. (2008). Corporate Financial Disclosure in Emerging Markets: The case of the UAE (Doctoral Dissertation, Griffith University, UK). Retrieved from https://www120.secure.griffith.edu.au/.../Al-Zarouni_2009_02Thesis.

Ando, R. (2015, July 21). Toshiba CEO quits over accounting scandal. Reuters. Retrieved from http://www.reuters.com/article/us-toshiba-accounting-stocks 
Archambault, J., \& Archambault, M. (2003).A multinational test of determinants of corporate disclosure. International Journal of Accounting, 38(2), 173-194. https://doi.org/10.1016/S0020-7063(03)00021-9

Ball, R., \& Brown, P. (1968).An empirical evaluation of accounting income numbers. Journal of Accounting Research, 6(2) 59-178. https://doi.org/10.2307/2490232

Beaver, W. (1968). The information content of annual earnings announcements. Journal of Accounting Research, 6, 67-92. https://doi.org/10.2307/2490070

Belkaoui, A., \& Kahl, A. (1978). Corporate financial disclosure in Canada, 6(2), 44-55. Vancouver: Canadian Certified General Accountants Association.

Belkaoui, R.A. (2004). Accounting Theory. London: Thomson Learning.

Buzby, S. L. (1974). Selected items of information and their disclosure in annual reports. The Accounting Review, 49(3), 423-435.

Camfferman, K., \& Cooke, T.E. (2002).An analysis of disclosure in the annual reports of UK and Dutch companies. Journal of International Accounting Research, 5(1), 3-30. https://doi.org/10.2308/jiar.2002.1.1.3

Cerf, A. R. (1961). Corporate Reporting and Investment Decisions. Berkeley: University of California Press.

Choi, F.D.S. (1973). Financial disclosure and entry to the European capital market. Journal of Accounting Research, 11(2), 159-175. https://doi.org/10.2307/2490187

Cooke, T. E. (1989a). Disclosure in the corporate annual reports of Swedish companies. Accounting and Business Research, 19(74), 113-124. https://doi.org/10.1080/00014788.1989.9728841

Cooke, T.E. (1992). The impact of size, stock market listing and industry type on disclosure in the annual reports of Japanese listed corporations. Accounting and Business Research, 22(87), 229-237. https://doi.org/10.1080/00014788.1992.9729440

Cooke, T.E., \& Wallace, R.S.O. (1989). Global survey of corporate disclosure practices and audit firms: A review essay. Accounting and Business Research, Winter, 47-57 https://doi.org/10.1080/00014788.1989.9729394

Factbook. (2014). Nigerian Stock Exchange

Fama, E. F., \& Jensen, M. C. (1983).Separation of ownership and control. Journal of Law and Economics, 26(3), 301-325. https://doi.org/10.1086/467037

Gibbins, M., Richardson, A., \& Waterhouse, J. (1990). The management of corporate financial disclosure: opportunism, ritualism, policies, and processes. Journal of Accounting Research, 28(1), 121-143. https://doi.org/10.2307/2491219

Gordon, M. (1964).Postulates, principles and research in accounting. The Accounting Review, $39(2), 251-263$. 
Gouws, D.G., \& Cronje, C.J. (2008). Corporate annual reports: accounting practices in transition.' South African Business Review, 12(2), 108-133.

Hajian, N., \& Rostami, A. A. (2014). Transparency and disclosure indices in emerging markets. The Macrotheme Review, 3(3), 73-82

Healy, P. M., \& Palepu, K. G. (2001). Information asymmetry, corporate disclosure, and the capital markets: A review of the empirical disclosure literature. Journal of Accounting and Economics, 31(1-3), 405-440. https://doi.org/10.1016/S0165-4101(01)00018-0

Iatridis, G. (2008). Accounting disclosure and firms' financial attributes: Evidence from the UK stock market. International Review of Financial Analysis, 17(2), 219-241. https://doi.org/10.1016/j.irfa.2006.05.003

Ibrahim, L. (2014). Accounting information disclosure by selected Nigerian deposit money banks (Unpublished Master's Dissertation), Usmanu Danfodiyo University, Sokoto, Nigeria

Iyoha, M. A. (2004). Applied econometrics. Benin City, Nigera: Mindex Press.

Jaggi, B., \& Low, P.Y. (2000). Impact of culture, market forces, and legal system on financial disclosures. International Journal of Accounting, 35(4), 495-519. https://doi.org/10.1016/S0020-7063(00)00076-5

Jensen, M. C. (1983). The modern industrial revolution, exit and the failure of internal control systems. The Journal of Finance, 48(3), 831-880. https://doi.org/10.1111/j.1540-6261.1993.tb04022.x

Kiyanga, B. P. L. (2014).Corporate disclosure quality: A comparative study of Botswana and South Africa. Unpublished Master's Thesis, University of South Africa.

Kohler, E. L. (1957). A dictionary for accountants. Englewood Cliff, N.J.: Prentice

Lang, M., \& Lundholm, R. (1993). Cross sectional determinants of analyst rating of corporate disclosures. Journal of Accounting Research, 31(2), 246-271. https://doi.org/10.2307/2491273

Lee, M. D. P. (2012). A review of the theories of corporate social responsibility: Its evolutionary path and the road ahead. International Journal of Management Reviews, 10(1), 53-73. https://doi.org/10.1111/j.1468-2370.2007.00226.x

Modugu, K.P. \& Eboigbe, S.U. (2017). Corporate attributes and corporate disclosure level of listed Companies in Nigeria: A Post-IFRS Adoption Study. Journal of Finance and Accounting, 5(2), 44-52. https://doi.org/10.12691/jfa-5-2-3

Moore, L., \& Buzby, S. (1972). The quality of corporate financial disclosure: A comment. Accounting Review, July, 581-584.

Naser, K,Al-Khatib,K.,\& Karbhari,Y. (2002). Empirical evidence on the depth of corporate information disclosure in developing countries: The Case of Jordan. International Journal of Commerce and Management, 12(3-4), 122-155. https://doi.org/10.1108/eb047456 
Naser, K. \& Al-Khatib, K (2000). Determinants of the depth of voluntary disclosure in the directors statement in a sample of Jordanian listed companies. Advanced in International Accounting, 13, 99-118.

Naser, K. (1998). Comprehensiveness of disclosure of non-financial companies listed on the amman financial market. International Journal of Commerce and Management, 8(1) 88-119. https://doi.org/10.1108/eb047365

Nweke, S. (2009, March 19). ANAN commends senate on financial reporting council bill. The Guardian. Retrieved, from www.ngrguardiannews.com/.../indexn3_html.

Okike, E., Adegbite, E., Nakpodia, F., \& Adegbite, S. (2015).A review of internal and external influences on corporate governance and financial accountability in Nigeria. International Journal of Business Governance and Ethics, 10(2), 65-185 https://doi.org/10.1504/IJBGE.2015.070933

Okike, E.N.M. (2000). Extension of information in accounting reports: An investigation. Nigerian Financial Review, 3(2).

Okunbor, J.A. (2016). Firm Characteristics and Financial Reporting Quality in Nigerian Quoted Companies. (Unpublished Doctoral Thesis). University of Benin, Benin City, Nigeria

Omran, M. \& El-Galfy, A.M. (2014). The theoretical perspective on corporate disclosure: A critical evaluation and literature survey. European Journal of Marketing, 8(4) 257-286. https://doi.org/10.1108/ARA-01-2014-0013

Owusu-Ansah, S. (1998a). The adequacy of corporate mandatory disclosure practices on emerging markets: A case study of the Zimbabwe stock exchange (Unpublished Doctoral Thesis). Middlesex University, London, UK.

Owusu-Ansah, S. (1998b). The impact of corporate attributes on the extent of mandatory disclosures and reporting by listed companies in Zimbabwe. The International Journal of Accounting, 33(5), 603-631. https://doi.org/10.1016/S0020-7063(98)90015-2

Parker, R.H. (1992). The Macmillan dictionary of accounting, London: Macmillan. https://doi.org/10.1007/978-1-349-22431-9

Qu, W. (2011).A study of voluntary disclosure by listed firms in China (Unpublished PhD Thesis). Deakin University, China.

SEC (2016). Order Instituting Public Administration and Cease-and-Desist Proceedings, United States of America

Shehata, N.F., Dahawy, K. \& Ismail, T. (2014). The relationship between firm characteristics and mandatory disclosure Level: When Egyptian accounting standards were first adopted. Mustang Journal of Accounting and Finance, 5, 85-103.

Singhvi, S.S., \& Desai, H.B. (1971).An empirical analysis of the quality of corporate financial disclosure. The Accounting Review, 46(1), 129-138. 


\section{Macrothink}

Asian Journal of Finance \& Accounting

ISSN 1946-052X

2017, Vol. 9, No. 2

Skinner, D. (1995). Do SEC's Safe habour provisions encourage forward-looking disclosures? Financial Analyst, July-August, 38-44.

Solomon, J. (2013). Corporate governance and accountability. United Kingdom: John Wiley \& Sons.

Sternberg, E. (1997). The defects of stakeholder theory. Scholarly Research Theory Papers, 5(1), 3-10. https://doi.org/10.1111/1467-8683.00034

Umoren, A.O. (2009). Accounting Disclosures and Corporate Attributes (Unpublished Doctoral Thesis). Covenant University, Ota, Nigeria.

Wallace, R. S. O., \& Naser, K. (1995). Firm-Specific determinants of the comprehensiveness of mandatory disclosure in the corporate annual reports of firms listed on the stock exchange of Hong Kong. Journal of Accounting and Public Policy, 14(4), 311-368. https://doi.org/10.1016/0278-4254(95)00042-9

Wallace, R. S.O., Naser, K.,\& Mora, A. (1994). The relationship between the comprehensiveness of corporate annual reports and firm characteristics in Spain. Accounting and Business Research, 25(97), 41-53. https://doi.org/10.1080/00014788.1994.9729927

Watts, R. L., \& Zimmerman, J. L. (1986). Positive accounting theory, Englewood Cliffs, NJ: Prentice-Hall

Watts, R.L., \& Zimmerman, J.L. (1990). Positive accounting theory: A ten year Perspective. The Accounting Review, 65(1), 131-156.

Yamane, T. (1967). Statistics: An Introductory Analysis. New York: Harper and Row. 